Jurnal Perikanan (2020) Volume 10. No. $1: 77-83$

DOI : https://doi.org/10.29303/jp.v10i1.155

\title{
KANDUNGAN KAROTENOID PADA IKAN MAS KOKI (Carassius auratus) YANG DIBERI TEPUNG LABU KUNING, TEPUNG WORTEL DAN TEPUNG SPIRULINA
}

\section{CAROTENOID OF GOLD FISH (Carassius auratus) GIVEN BY PUMPKIN FLOUR, CARROT FLOUR AND SPIRULINA}

\author{
Khairunnisa $^{1 *}$, Saptono Waspodo ${ }^{2)}$, Bagus Dwi Hari Setyono ${ }^{1)}$ \\ ${ }^{1)}$ Program Studi Budidaya Perairan Universitas Mataram \\ ${ }^{2)}$ Program Studi Ilmu Kelautan Universitas Mataram \\ *)alamat korespondensi : khairunnisa.icak@gmail.com
}

\begin{abstract}
Abstrak
Warna merupakan salah satu faktor yang paling berpengaruh terhadap harga jual ikan hias akan tetapi warna ikan hias pada umumnya menjadi pudar pada saat dipelihara di dalam akuarium. Tujuan dari penelitian ini adalah untuk mengetahui kandungan Karotenoid ikan mas koki (Carassius auratus) setelah diberi pakan tambahan berupa tepung labu kuning, tepung wortel serta tepung spirulina. Penelitian ini dilaksanakan pada 30 Mei hingga 29 Juni 2019. Penelitian ini menggunakan metode Rancangan Acak Lengkap (RAL) dengan 4 perlakuan dan 3 kali ulangan masing-masing 15 ekor ikan tiap unit, dan terdapat empat dosis perlakuan. P0 (pakan tanpa penambahan pakan lain), P1 (pakan dengan 15\% tepung labu kuning), P2 (pakan dengan 5\% tepung wortel), P3 (pakan dengan 1,2\% tepung spirulina). Nilai TCF tertinggi yaitu pada P2 (penambahan tepung wortel 5\%) dengan nilai 6,4 dan terendah pada P0 (tanpa penambahan tepung) dengan nilai 3,7. Kandungan Karotenoid tertinggi yaitu pada P2 (penambahan tepung wortel 5\%) dengan dengan nilai $11,19 \mu \mathrm{mol} / \mathrm{g}$ sedangkan kandungan terendah yaitu pada P0 (tanpa penambahan tepung) dengan nilai 4,65 $\mu \mathrm{mol} / \mathrm{g}$. Perlakuan tersebut tidak memberikan pengaruh nyata pada pertumbuhan berat dan panjang ikan mas koki.
\end{abstract}

Kata kunci : Ikan Mas Koki, Karotenoid, TCF

\begin{abstract}
Color is one of the most influential factors on the selling price of ornamental fish, but the color of ornamental fish generally fades when kept in an aquarium. The purpose of this study was to determine the carotenoid content of goldfish (Carassius auratus) after being given additional feed in the form of pumpkin flour, carrot flour and spirulina flour. This research was conducted from 30 May to 29 June 2019. This study used a Completely Randomized Design (CRD) method with 4 treatments and 3 replications each of 15 fish per unit, and there were four treatment doses. P0 (without the addition), P1 (with 15\% pumpkin flour), P2 (with 5\% carrot flour), $\mathrm{P} 3$ (with $1.2 \%$ spirulina flour). The highest TCF value is in $\mathrm{P} 2$ (addition of 5\% carrot flour) with a value of 6.4 and the lowest in $\mathrm{P0}$ (without the addition) with a value of 3.7. The highest carotenoid content is in P2 (5\% addition of carrot flour) with a value of 11.19 $\mu \mathrm{mol} / \mathrm{g}$ while the lowest content is in P0 (without the addition) with a value of $4.65 \mu \mathrm{mol} / \mathrm{g}$. The treatment did not have a significant effect on the growth and weight of the goldfish.
\end{abstract}

Keywords : Goldfish, Carotenoids, TCF 


\section{PENDAHULUAN}

Salah satu keanekaragaman hayati yang dimiliki Indonesia dan patut dibanggakan adalah keragaman spesies ikan hias air tawar. Potensi wilayah perairan Indonesia memiliki keunikan dan keragaman ikan hias yang berlimpah hingga mendapat julukan home for hundred of exotic ornamental fish species. Terdapat 240 jenis ikan hias laut hidup (marine ornamental fish) dan 226 jenis ikan hias tawar hidup (fresh water ornamental fish) (Ramachandran, 2002 dalam Khoironi dan Saksara, 2017).

Indonesia merupakan eksportir ikan hias nomor 5 di dunia yang mampu mengambil pasar hingga 7,13\%. Jumlah ini masih kalah dari Singapura yang merupakan eksportir utama di dunia yang mencapai angka 12,44 \% (KKP, 2017). Pada tahun 2015 hingga 2018 jumlah ekspor ikan hias Indonesia telah mencapai 257.862.207 ekor, dimana negara tujuan didominasi ke Jepang, Singapore, United States, China, United Kingdom, Korea dan Malaysia (KKP, 2019).

Warna ikan hias merupakan salah satu faktor yang paling berpengaruh terhadap harga jual ikan tersebut. Ikan mas koki (Carassius auratus) termasuk salah satu jenis ikan hias yang memiliki warna kuning pudar hingga merah. Ikan ini sangat populer dan mempunyai nilai jual tinggi di forum perdagangan ikan hias. Harga jual ikan koki akan optimal jika warnanya terlihat kuning dan oranye kemerahan. Akan tetapi warna ikan hias pada umumnya menjadi pudar pada saat dipelihara di dalam akuarium. Salah satu penyebabnya adalah adanya stress lingkungan antara lain lingkungan berbeda antara akuarium dengan habitat asli, cahaya matahari, kualitas air, dan kandungan pigmen dalam pakan.

Faktor makanan memiliki pengaruh dalam pembentukan warna ikan hias (Nazhira et al., 2017). Kromatofora merupakan sel pigmen yang menyebabkan terbentuknya warna pada ikan. Kromatofora terdapat dalam dermis pada sisik, di luar maupun di bawah sisik. Warna merah atau kuning merupakan warna yang banyak mendominasi ikan hias. Pigmen karotenoid adalah komponen utama pembentuk pigmen merah dan kuning (Satyani \& Sugito, 1997 dalam Subamia et al., 2013).

$\beta$-karoten merupakan salah satu dari sekitar 500 karotenoid yang ada di alam dan mempunyai aktivitas Vitamin A paling tinggi. Beberapa sumber $\beta$-karoten tinggi yaitu labu kuning, wortel serta spirulina. Adapun kandungan $\beta$-karoten pada labu kuning sebesar $1,18 \mathrm{mg} / 100 \mathrm{~g}$ (Yulianawati dan Isworo, 2012), wortel sebesar 74,05 mg/100 g (Taqiyuddin, 2015) dan $\beta$-karoten pada fitoplankton Spirulina plantesis mempunyai kadar sebesar 8,79 mg/g (Salam, 2017). Namun, jika mengkonsumsi terlalu banyak $\beta$ karoten akan dapat membahayakan karena mengandung substansi nitrosamid, nitrit, dan falcarinol (Taqiyuddin, 2015).

Kandungan $\beta$-karoten pada ikan dapat diukur dengan menggunakan metode spektrofotometri. Spektrofotometri merupakan suatu metode analisa yang didasarkan pada pengukuran serapan sinar monokromatis oleh suatu lajur larutan berwarna pada panjang gelombang spesifik dengan menggunakan monokromator prisma atau kisi difraksi dengan detector fototube (Taqiyuddin, 2015).

Tujuan dari penelitian ini adalah untuk mengetahui laju pertumbuhan spesifik, peningkatan kecerahan warna, dan kandungan karotenoid ikan mas koki (C. auratus) setelah diberi pakan tambahan berupa tepung labu kuning, tepung wortel serta tepung spirulina.

\section{METODE PENELITIAN}

Penelitian ini dilaksanakan pada bulan 30 Mei hingga 29 Juni 2019 selama 30 hari dan dilakukan di instalasi budidaya ikan milik pribadi di Kecamatan Ampenan, Kota Mataram serta Laboratorium Kimia, Fakultas Matematika dan Ilmu Pengetahuan Alam. Penelitian ini menggunakan metode eksperimental 
dengan pola Rancangan Acak Lengkap (RAL) dengan 4 perlakuan dan 3 kali ulangan sehingga diperoleh 12 unit percobaan masing-masing 15 ekor ikan tiap unit, dan terdapat empat dosis perlakuan.

P0: Pakan tanpa penambahan pakan lain (kontrol)

P1: Pakan dengan $15 \%$ tepung labu kuning P2: Pakan dengan 5\% tepung wortel P3: Pakan dengan 1,2\% tepung spirulina

Parameter yang diamati dalam penelitian ini adalah penyerapan karotenoid, peningkatan kualitas warna, dan pertumbuhan panjang dan berat pada ikan mas koki setelah diberi pakan selama jangka waktu tertentu selama perlakuan.

Analisis warna dilakukan melalui pengamatan secara visual dan analisis karotenoid. Analisis peningkatan kualitas warna dilakukan dengan menggunakan metode Toca Color Finder (Indarti et al., 2012). Penentuan skor warna menggunakan kertas Toca Color Finder oleh 3 panelis yang tidak buta warna. Analisis karotenoid dilakukan untuk mengetahui besarnya penyerapan karotenoid yang diberikan melalui pakan, dengan perhitungan mengacu pada rumus Henry dan Gime (1993).

Data dianalisis menggunakan Microsoft Excel 2007 dan Analysis Of Variance (ANOVA), apabila terdapat perbedaan yang nyata, dilakukan uji lanjut menggunakan Duncan Multiple Range Test (DMRT) pada taraf nyata 0,05 .

\section{HASIL DAN PEMBAHASAN Laju Pertumbuhan Spesifik}

Parameter pertumbuhan yang diamati pada penelitian adalah laju pertumbuhan berat dan laju pertumbuhan panjang ikan mas koki. Hasil dari pengukuran laju pertumbuhan berat dan panjang selama masa pemeliharaan dapat dilihat pada Tabel 1.

Tabel 1. Laju Pertumbuhan Berat, Laju Pertumbuhan Panjang, dan Kelangsungan Hidup

\begin{tabular}{lllll}
\hline No & Perlakuan & $\begin{array}{l}\text { Laju Pertumbuhan } \\
\text { Berat (\%) }\end{array}$ & $\begin{array}{l}\text { Laju Pertumbuhan } \\
\text { Panjang }(\%)\end{array}$ & $\begin{array}{l}\text { Kelangsungan } \\
\text { Hidup }(\%)\end{array}$ \\
\hline 1 & P0 & $1,73 \mathrm{a}$ & $1,73 \mathrm{a}$ & $80,00 \mathrm{a}$ \\
2 & P1 & $1,73 \mathrm{a}$ & $1,76 \mathrm{a}$ & $88,89 \mathrm{a}$ \\
3 & P2 & $1,67 \mathrm{a}$ & $1,70 \mathrm{a}$ & $84,44 \mathrm{a}$ \\
4 & P3 & $1,78 \mathrm{a}$ & $1,77 \mathrm{a}$ & $86,67 \mathrm{a}$ \\
\hline
\end{tabular}

Berdasarkan Tabel 1 terlihat bahwa laju pertumbuhan berat ikan mas koki pada tiap perlakuan mengalami peningkatan, pada P0 (tanpa penambahan tepung) $1,73 \%$, P1 (penambahan tepung labu kuning $15 \%$ ) yaitu $1,73 \%, \quad \mathrm{P} 2$ (penambahan tepung wortel 5\%) yaitu 1,67\%, dan P3 (penambahan tepung spirulina $1,2 \%$ ) yaitu $1,78 \%$. Laju pertumbuhan panjang juga mengalami peningkatan, pada P0 yaitu $1,73 \%, \mathrm{P} 1$ yaitu $1,76 \%, \mathrm{P} 2$ yaitu $1,70 \%$ dan $\mathrm{P} 3$ yaitu $1,77 \%$.

Berdasarkan hasil ANOVA pada laju pertumbuhan spesifik berat dan panjang ikan mas koki menunjukkan bahwa penambahan tepung labu kuning, tepung wortel dan tepung spirulina terhadap pertumbuhan tidak berbeda nyata. Hal ini sesuai dengan pernyataan Sulawesty (1997) dalam Solihah et al. (2015) bahwa penambahan karotenoid pada pakan tidak berpengaruh pada pertumbuhan. Menurut Ramadhan (2014) dalam Nazhira et al. (2017) penambahan karotenoid pada pakan tidak berpengaruh terhadap pertumbuhan ikan hias yang diberi pakan sumber karoten. Ikan diduga lebih memanfaatkan karotenoid tesebut untuk meningkatkan warna tubuhnya. 


\section{Kelangsungan Hidup (Survival Rate)}

Tingkat kelangsungan hidup (survival rate) ikan mas koki pada setiap perlakuan memiliki nilai yang tidak berbeda nyata. Berdasarkan Tabel 1 terlihat bahwa nilai survival rate (SR) pada P0 yaitu $80 \%$, P1 yaitu $88,89 \%$, P2 yaitu $84,44 \%$ dan P3 yaitu $86,67 \%$.
Kualitas air untuk pemeliharaan perlu dijaga agar tidak menimbulkan stress pada ikan. Nilai kualitas air harus optimal sesuai standar untuk pemeliharaan ikan hias. Selama masa pemeliharaan nilai kualitas air dapat dilihat pada Tabel 2.

Tabel 2. Kualitas Air

\begin{tabular}{lllll}
\hline No & Parameter & Satuan & Nilai & Referensi \\
\hline 1 & Suhu & ${ }^{\circ} \mathrm{C}$ & $23-26$ & $22-27^{\circ} \mathrm{C}($ Lesmana, 2007) \\
2 & $\mathrm{pH}$ & - & $6,9-8,7$ & $6,5-8,0$ (Lesmana, 2007) \\
3 & DO & $\mathrm{ppm}$ & $4,2-6,4$ & $>3 \mathrm{mg} / \mathrm{L}($ Antono, 2010) \\
\hline
\end{tabular}

Parameter kualitas air yang diukur pada penelitian ini adalah suhu, $\mathrm{pH}$ dan DO. Selama penelitian, suhu berkisar antara $23-26^{\circ} \mathrm{C}$. Menurut Lesmana (2002) dalam Fitriana et al. (2013) suhu ini masih dalam batas optimal untuk pemeliharaan ikan yaitu berkisar antara $22-27^{\circ} \mathrm{C}$. $\mathrm{pH}$ air selama penelitian berkisar antara 6,9-8,7. Menurut Lesmana (2007) dalam KaroKaro et al. (2014) bahwa pH optimal untuk pemeliharaan ikan mas koki yaitu berkisar antara 6,5-8,0 sehingga tidak akan mempengaruhi pertumbuhan dan kelangsungan hidup ikan. Sedangkan nilai DO selama pemeliharaan berkisar antara
4,2-6,4 mg/l dimana nilai tersebut merupakan nilai optimum sesuai dengan pernyataan Antono (2010) dalam Solihah et al. (2015) bahwa DO >3 mg/l baik untuk kehidupan dan pertumbuhan ikan.

\section{Peningkatan Kualitas Warna}

Selama masa pemeliharaan diperoleh data ikan mas koki mengalami perubahan warna. Perubahan ini diketahui dengan menguji ikan dengan Test Organo Visual menggunakan Toca Color Finder (TCF). Hasil pengujian kecerahan warna dengan menggunakan Toca Color Finder (TCF) dapat dilihat pada Gambar 1.

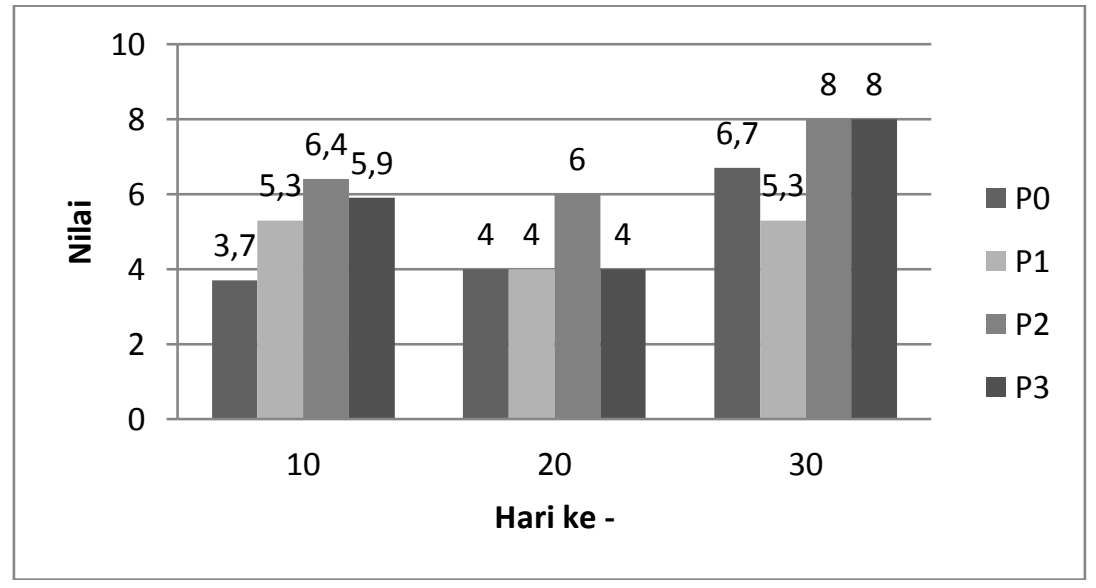

Gambar 1. Peningkatan Kualitas Warna Ikan Mas Koki

Hasil pengamatan menunjukkan bahwa ikan mas koki mengalami penurunan kualitas warna pada hari ke 20 namun mengalami kenaikan pada hari ke
30. Penurunan kualitas warna ini terjadi diduga karena ikan mengalami stress saat pengambilan sampel untuk pengamatan 
warna (test organo visual) dengan menggunakan TCF.

Saat pengamatan warna, ikan dikeluarkan dari akuarium untuk diamati warnanya di atas kertas TCF. Kekurangan oksigen salah satu penyebab ikan mengalami stress. Menurut Antono (2010) dalam Karo-Karo et al. (2014) bahwa stress pada ikan mas koki atau ikan hias umumnya akan berdampak negatif pada warna ikan. Dengan pernyataan ini diduga bahwa penurunan kualitas warna terjadi bukan karena penambahan tepung pada pakan. Untuk mengurangi peluang terjadinya stress pada ikan ada baiknya memberikan durasi saat melakukan pengamatan agar ikan tidak kehabisan oksigen dan stress.

\section{Penyerapan Karotenoid}

Ikan yang memakan pakan yang diberi pakan tambahan berupa tepung labu kuning $15 \%$, tepung wortel $5 \%$ dan tepung spirulina $1,2 \%$ mengalami peningkatan pada jumlah karotenoid di dalam tubuh ikan seteleh di uji menggunakan spektrofotometer. Hasil pengamatan jumlah karotenoid pada masa pemeliharaan dapat dilihat pada Gambar 2.

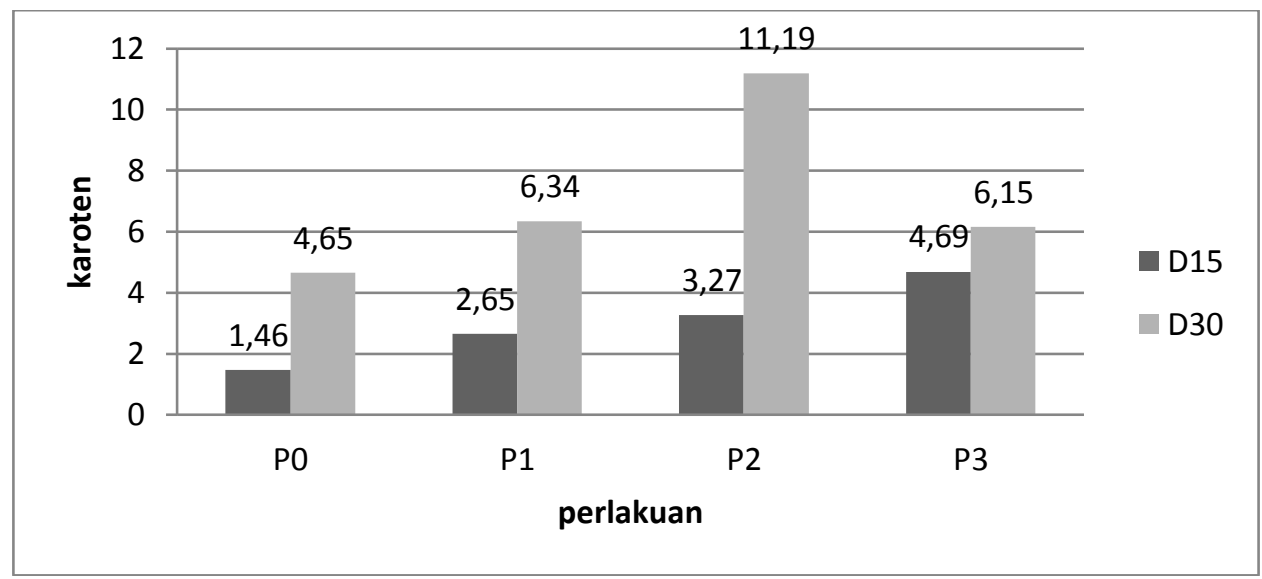

Gambar 2. Kandungan Karotenoid Pada Ikan Mas Koki

Peningkatan jumlah karotenoid dapat terjadi karena penambahan tepung labu kuning, wortel, dan spirulina pada pakan ikan mas koki. Terjadinya penambahan tepung labu kuning, wortel, dan spirulina berarti terjadi pula penambahan jumlah karotenoid pada pakan. Ikan mas koki menyerap karotenoid pada pakan yang telah ditambahkan tepung labu kuning 15\%, tepung wortel $5 \%$, dan tepung spirulina $1,2 \%$. Pada perlakuan P0 jumlah karotenoid pada 15 hari pertama sebesar 1,46 $\mu \mathrm{mol} / \mathrm{g}$ kemudian meningkat pada hari ke-30 menjadi 4,65 $\mu \mathrm{mol} / \mathrm{g}$. Sedangkan pada P1 jumlah karotenoid pada hari ke-15 sebesar 2,65 $\mu \mathrm{mol} / \mathrm{g}$ dan meningkat menjadi $6,34 \mu \mathrm{mol} / \mathrm{g}$ pada hari ke-30. Pada perlakuan P2 kandungan karotenoid sebesar 3,27 $\mu \mathrm{mol} / \mathrm{g}$ pada hari ke-15 dan meningkat menjadi 11,19 $\mu \mathrm{mol} / \mathrm{g}$ pada hari ke-30. Pada perlakuan P3 kandungan karotenoid sebesar 4,69 $\mu \mathrm{mol} / \mathrm{g}$ pada hari ke-15 dan meningkat pada hari ke-30 menjadi 6,15 $\mu \mathrm{mol} / \mathrm{g}$. Menurut Subamia et al. (2010) peningkatan pigmen warna pada tubuh ikan akan meningkat saat ditambahkan sumber peningkat warna dalam pakan. Walaupun warna ikan tidak mengalami peningkatan setelah ditambahkan sumber peningkat warna, minimal ikan mampu mempertahankan pigmen warna pada tubuhnya selama masa pemeliharaan.

Hasil pengamatan menunjukkan kandungan karotenoid yang berbeda pada setiap perlakuan. Peningkatan jumlah karotenoid pada setiap ikan berbeda-beda sesuai dengan kemampuan ikan tersebut untuk menyerap karotenoid pada pakan 
yang diberikan. Karotenoid akan diserap ke dalam sel pigmen melalui berbagai proses. Penyebaran sel pigmen menjadi salah satu faktor meningkat atau menurunnya warna pada ikan. Sesuai dengan pernyataan Kusuma (2012) dalam Noviyanti et al. (2015) bahwa proses meningkatnya intensitas warna diawali dengan karotenoid yang ada dalam pakan kemudian dialirkan melalui aliran darah dan disimpan dalam jaringan lemak untuk di deposit pada kromatofora yang terdapat dalam dermis. Jumlah sel pigmen dalam tubuh ikan mempengaruhi warna pada ikan tersebut. Jika penebaran sel pigmen merata maka warna tubuh ikan akan tampak lebih pekat, tetapi jika penebarannya pada satu titik inti sel maka warna tubuh akan menjadi pucat.

\section{KESIMPULAN}

Penambahan tepung labu kuning $15 \%$, tepung wortel $5 \%$ dan tepung spirulina $1,2 \%$ menunjukkan laju pertumbuhan berat dan laju pertumbuhan panjang yang tidak berbeda nyata. Kecerahan warna mengalami peningkatan pada semua perlakukan yaitu pada hari ke 30. Kandungan karotenoid menunjukkan hasil yang meningkat untuk semua perlakukan, Kandungan karotenoid tertinggi yaitu pada penambahan tepung wortel 5\% dengan dengan nilai 11,19 $\mu \mathrm{mol} / \mathrm{g}$ sedangkan kandungan terendah yaitu pada kontrol yaitu tanpa penambahan tepung dengan nilai $4,65 \mu \mathrm{mol} / \mathrm{g}$.

\section{DAFTAR PUSTAKA}

Fitriana. N., Subamia, I.W., Wahyudi, S. 2013. Pertumbuhan dan Performansi Warna Ikan Mas Koki (Carassius sp.) melalui Pengayaan Pakan dengan Kepala Udang. Jurnal Biologi Al Kauniyah. Volume 6 Nomor 1 Tahun 2013.

Karo-Karo R. M. S., Usman, S., dan Irwanmay. 2015. Pengaruh Konsentrasi Tepung Wortel (Daucus carota) pada Pakan terhadap Peningkatan Warna Ikan Mas Koki
(Carassius auratus). J.

Aquacoastmarine. Volume 10 Nomor 5 Halaman 1-10.

Khoironi, F.E. dan Saksara, I.A.N. 2017. Analisis Pengaruh Kurs Dollar, Inflasi, dan Produksi terhadap Ekspor Ikan Hias di Provinsi Bali. E-Jurnal Ekonomi Pembangunan Universitas Udayana. Volume 6 Nomor 3 Tahun 2017.

Kementrian Kelautan dan Perikanan. 2017. KKP Dorong Indonesia Rajai Pasar Ikan Hias Dunia. https://kkp.go.id/artikel/1100-kkpdorong-indonesia-rajai-pasar-ikanhias-dunia [Diakses pada tanggal 27 Agustus 2019]

Kementrian Kelautan dan Perikanan. 2019. KKP Serius Garap Potensi Budidaya Ikan Hias Nasional. https://kkp.go.id/djpb/artikel/12566kkp-serius-garap-potensi-budidayaikan-hias-nasional [Diakses pada tanggal 27 Agustus 2019]

Nazhira S., Safrida, Sarong, M.A. 2017. Pengaruh Penambahan Tepung Labu Kuning (Cucurbita moschata D.) dalam Pakan Buatan terhadap Kualitas Warna Ikan Maskoki (Carassius auratus). Jurnal Ilmiah Mahasiswa Fakultas Keguruan dan Ilmu Pendidikan Unsyiah. Volume 2 Nomor 2 Tahun 2017.

Noviyanti K., Tarsim, Maharani, H.W. 2015. Pengaruh Penambahan Tepung Spirulina pada Pakan Buatan terhadap Intensitas Warna Ikan Mas Koki (Carassius auratus). E-Jurnal Rekayasa dan Teknologi Budidaya Perairan. Volume 3 Nomor 2 Tahun 2015.

Riantono, F., Kismiyati, Sulmartiwi, L. 2016. Perubahan Hematologi Ikan Mas Komet (Carassius auratus auratus) Akibat Infestasi Argulus Japonicus Jantan dan Argulus Japonicus Betina. Journal of Aquaculture and Fish Health. Volume 5 Nomor 2 Tahun 2016. 
Salam, A. 2017. Pemanfaatan Fitoplankton Spirulina platensis Kaya $\beta$-Karoten, Docosahexaenoic acid (DHA), Eicosapentaenoic (EPA) dan Protein Pada Fortifikasi Nugget Jagung. Skripsi. Unpublish. Fakultas Matematika dan Ilmu Pengetahuan Alam Universitas Hasanuddin, Makassar.

Solihah, R., Buwono, I.D., Herawati, T. 2015. Pengaruh Penambahan Tepung Labu Kuning dan Tepung Kepala Udang terhadap Peningkatan Kualitas Warna Ikan Mas Koki (Carassius auratus). Jurnal Perikanan Kelautan. Volume 6 Nomor 2 (1) Tahun 2015.

Subamia, I.W., Meilisza, N., Permana, A. 2013. Peningkatan Kualitas Warna Kuning dan Merah serta Pertumbuhan
Benih Ikan Koi melalui Pengayaan Tepung Kepala Udang dalam Pakan. Jurnal Riset Akuakultur. Volume 8 Nomor 3 Tahun 2013.

Taqiyuddin M. Z. 2015. Analisa $\beta$-Karoten pada Wortel (Daucus carota) dengan Menggunakan Spektrofotometer Tampak. Skripsi. Unpublish. Fakultas Teknik Universitas Diponegoro, Semarang.

Yulianawati, T.A. dan Isworo, J.T. 2012. Perubahan Kandungan Beta Karoten, Total Asam, dan Sifat Sensorik Yoghurt Labu Kuning Berdasarkan Lama Simpan dan Pencahayaan. Jurnal Pangan dan Gizi. Volume 3 Nomor 1 Tahun 2012. 